\title{
RUMINAL FERMENTATION AND BLOOD GLUCOSE AT LOW AND HIGH LEVEL INTAKE OF GROWING AND MATURE KACANG GOAT
}

\author{
N. Luthfi ${ }^{1}$, C. M. S. Lestari ${ }^{2}$ and A. Purnomoadi ${ }^{2}$

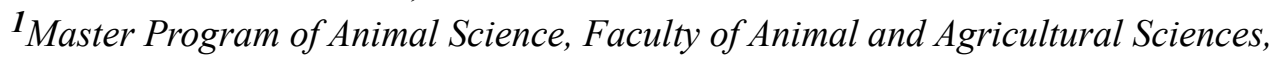 \\ Diponegoro University, Tembalang Campus, Semarang 50275 - Indonesia \\ ${ }^{2}$ Faculty of Animal and Agricultural Sciences, Diponegoro University, \\ Tembalang Campus, Semarang 50275 - Indonesia \\ Corresponding E-mail : agung194@yahoo.com
}

Received July 08, 2014; Accepted August 29, 2014

\begin{abstract}
ABSTRAK
Tujuan dari penelitian ini adalah untuk membandingkan konsentrasi Volatile Fatty Acids (VFA) rumen dan kadar glukosa darah antara kambing Kacang muda dan dewasa dengan level pakan berbeda. Delapan ekor umur muda (6-7 bulan) dengan bobot badan (BB) 12,75 $\pm 2,67 \mathrm{~kg}$ dan 8 ekor umur dewasa (8-12 bulan) dengan BB 34 $\pm 3,32 \mathrm{~kg}$. Pakan yang diberikan berupa pakan komplit bentuk pellet dengan kandungan protein kasar (PK) 18,8\% dan total digestible nutrients (TDN) 78,82\%. Pakan diberikan dalam 2 level yaitu rendah (low feeding; mendekati 1 kali hidup pokok) dan tinggi (high feeding; mendekati 2 kali hidup pokok). Rancangan percobaan yang digunakan adalah pola tersarang (nested design). Data yang diukur adalah konsumsi pakan harian, kecernaan pakan dengan metode total koleksi, konsentrasi VFA rumen dan glukosa darah. Data yang diperoleh dianalisis dengan sidik ragam. Hasil penelitian menunjukkan adanya perbedaan yang nyata $(\mathrm{P}<0,05)$ pada konsumsi $\mathrm{BK}$ pakan, karbohidrat tercerna, serat kasar tercerna, dan bahan organik tercerna pada perlakuan umur, sedangkan level pakan memberikan pengaruh yang sangat nyata $(\mathrm{P}<0,001)$ terhadap konsumsi bahan kering $(\mathrm{BK})$ pakan, karbohidrat tercerna, serat kasar tercerna, dan bahan organik tercerna, tetapi baik umur maupun level pakan tidak memberikan pengaruh terhadap kecernaan $(\mathrm{P}>0,05)$. Konsentrasi VFA dan kadar glukosa darah tidak berbeda $(\mathrm{P}>0,05)$ baik pada umur muda maupun dewasa. Namun demikian, konsentrasi VFA jam ke 3 dan jam ke 6 pada high feeding lebih tinggi dibandingkan low feeding, sedangkan glukosa darah high feeding lebih tinggi pada jam ke 3 dari pada low feeding.

Kata kunci : kambing Kacang, level pakan, umur, VFA, glukosa darah
\end{abstract}

\begin{abstract}
This study was conducted to compare ruminal Volatile Fatty Acids (VFA) concentration and blood glucose in young and mature Kacang goats at different feeding levels. Eigth male young Kacang goats weights at $12.75 \pm 2.68 \mathrm{~kg}$ (6-7 months) and male mature goat weights at $\pm 17.34 \pm 3.32 \mathrm{~kg}(8-12$ months) were used in this study. The pelleted complete feed was formulated to give $18,8 \%$ of Crude Protein (CP) and $78.82 \%$ of total digestible nutrients (TDN). The experiment design was nested design experimental $2 \times 2$ with 4 replications. The main factors (based on nested) were young and mature goats and the second factor was low feeding (near maintenance level) and high feeding ( $2 \mathrm{X}$ maintenance). Data measured were daily feed intake, feed digestibilities, ruminal VFA concentration and blood glucose. The data obtained were analyzed by using analysis of variance. The results showed that dry matter intake (DMI), digestible carbohydrates, digestible crude fiber, and digestible organic matter was affected by age $(\mathrm{P}<0.05)$, as well as level of feeding $(\mathrm{P}<0.001)$, but age and feeding level has no effect on digestibility $(\mathrm{P}>0.05)$. Ruminal VFA and blood glucose concentrations were found similar $(\mathrm{P}>0.05)$
\end{abstract}


neither in young and mature goats. However, VFA and concentration on the 3 and $6 \mathrm{~h}$ on high feeding as well as blood glucose on $3 \mathrm{~h}$ in high feeding were higher than those on low feeding.

Keywords : Kacang goats, level intake, age, VFA, blood glucose

\section{INTRODUCTION}

Ruminal fermentation process is the important stage for animal to utilize the nutrients in the diet. Breed is one of the factors affecting fermentation in the rumen due to the specific microbes in their rumen. Volatile fatty acids (VFA) as a fermentation product of carbohydrates in the rumen (Tillman et al., 1991; Cole et al., 1988) reached $94.52 \mathrm{mmoL}$ for sheep fed different levels of feeding with DM digestibility of $51.29 \%$ (Rezaei et al., 2014), while Granadina goats with DM digestibility of $65.03 \%$ has VFA concentration $74.15 \mathrm{mmoL}$ (Romero-Huelva and Molina-Alcaide, 2013). Blood glucose was obtained from the digestion of carbohydrates, VFA (Lykos et al., 1997; Rodriguez et al., 1997; Ponto and Bergen, 1994), glycolysis (Tillman et al., 1991; Sano et al., 1999) and obtained from the gluconeogenesis (Sano et al., 1999).

Blood glucose levels in young ruminants is higher than mature ruminants due to the development of rumen function, ration changes, and changes in metabolites purposes used as an energy source (Bergman, 1966). The blood glucose was affected by level of intakes (Sano et al., 1999; Peterson et al., 1993; Turner et al., 2005). The study on ruminal fermentation and blood glucose in Kacang goats was still limitedly done, and therefore this study was carried out to elucidate blood glucose produced by VFA concentration in young and mature Kacang goats at different level intakes.

\section{MATERIALS AND METHODS}

\section{Animals and Feeding Management}

Eight male young Kacang goats with body weights (BW) of $12.75 \pm 2.68 \mathrm{~kg}$ (6-7 months old) and eigth male mature goat with body weight of $17.34 \pm 3.32 \mathrm{~kg}$ (8-12 months old) were used in this study. They were separated into two groups for feeding treatment, i.e. low feeding and high feeding. The feed was given in form of pelleted diet consisted of $25 \%$ of wheat stalks, $32 \%$ of soybean meal, $39 \%$ of rice bran, $3 \%$ of molasses and $1 \%$ of minerals mixture to provide $18.8 \%$ of crude protein $(\mathrm{CP}) ; 78.82 \%$ of total digestible nutrients (TDN); $12.18 \%$ of crude fiber (Cfi);
$3.10 \%$ of extract eter (EE), $7.77 \%$ of ash; $58.15 \%$ of nitrogen free extract (NFE) and $5311 \mathrm{KJ} / \mathrm{g}$ of gross energy. The low feeding was given at $1.83 \%$ of BW, while high feeding was given at $2.74 \%$ of BW. Feeding was given twice a day at 07.00 and 16.00 .

\section{Experimental Procedures and Parameters Measured}

This research was conducted in three stages, namely adaptation stage (1 month), the preliminary stage ( 2 weeks), and data collection stage (10 weeks). Adaptation stage was conducted to provide animals adapted on feed and environment of the study and to determine the ability of goats to consume diet. In preliminary stage, the goats were randomly placed to the cage as well as to feeding treatment. During data collection stage, the feed was given and residuals was weighed to calculate daily feed consumption, while body weight was weekly weighed to calculate the body weight gain and to adjust feed amount in the following week. The feed utilization was determined by $7-d$ total feed and feces collection which was done in the middle of data collection period. The dry matter of feed and feces were determined by oven-drying in $135^{\circ} \mathrm{C}$ for 2 hours.

The experiment was conducted following experimental design $2 \times 2$ with 4 replications. The main factors (based on nested) were young and mature goats and the second factor was low feeding (near maintenance) and high feeding ( $2 \mathrm{X}$ maintenance):

YGLF= young Kacang goats with low feeding level $\mathrm{YGHF}=$ young Kacang goats with high feeding level MGLF= mature Kacang goats with low feeding level MGHF= mature Kacang goats with high feeding level

Rumen fluid and blood were taken at 0,3 , and 6 hours after feeding. The volatile fatty acids were analyzed using the Gas Chromatography (Isac et al., 1994), while Blood glucose was analyzed using glucose kit (Bavaria Diagnostica, Hamburg, Germany) and a spectrophotometer (Coomer et al., 1993).

\section{Data Analysis}

The results were analyzed by analysis of variance (Gomes and Gomez, 1995) by using the 
SPSS 16.0 program. The study on relationship between VFA and blood glucose was conducted by correlation regression.

\section{RESULTS AND DISCUSSIONS}

\section{Feed Intake}

The feed intake and its digestibility are presented in Table 1. The study found that level of feeding and ages gave an effect on goat production. Digestible of carbohydrate, Cfi, and $\mathrm{OM}$ for high feeding were greater than those of low feeding $(\mathrm{P}=0.001)$ while mature goats was higher than young goats $(\mathrm{P}<0.05)$ along with increasing DMI on high feeding $(\mathrm{P}<0.001)$. There were no difference between digestibility of carbohydrate, Cfi, and $\mathrm{OM}$ at level feeding and ages $(\mathrm{P}>0.05)$.

Along with increasing age, body weight increased and resulting in increasing DMI. Age at puberty was highly correlated with body weight (Short and Bellows, 1971; Hays and Brinks, 1980). As expected, feed intake in mature goats was higher than in young goats due to the body weight which highly correlated to dry matter requirements (Kearl, 1982; Hartadi et al., 1997; Lewis and Emmans 2010). DMI in this sudy was agreed with previous report of Tovar-Luna et al. (2010), Sahlu et al. (1999) and Puchala et al. (2011) that intake level increased DMI and OM in Angora goats. The consequences of the higher DMI and its digestibility was the body weight gain observed in mature and high feeding showed higher $(\mathrm{P}<0.05)$ than young and low feeding.

The digestibility of feed in this study was found similar because of similarity in feed quality given in this study while the rumen condition was in similar maturity of all animals eventhough the feed was given in different feeding level. This was confirmed by the previous studies of Tovar-Luna (2007), Fernandes et al. (2007) and Pralomkarm (1995).

\section{Volatile Fatty Acid (VFA) and Blood Glucose}

The VFA in the rumen and blood glucose are presented in Table 2. There were no differences in VFA and blood glucose concentration at different ages neither on the 0,3 or $6 \mathrm{~h}$. Slightly different result was found on blood glucose which high feeding was found higher $(\mathrm{P}<0.05)$ than low feeding only in $3 \mathrm{~h}$ post feeding.

The trend of VFA in the rumen was similar to the blood glucose which from 0 to $3 \mathrm{~h}$ was increased, and then from 3 to $6 \mathrm{~h}$ was decreased. The higher concentration of VFA found in $3 \mathrm{~h}$ post feeding was confirmed the reports of Rodriguez et al. (1997) and Lykos et al. (1997).

Similar feed digestibility and VFA concentration in rumen between young and mature goats indicated that rumen in young and mature goats was in similar maturity confirming rumen developed at an early age around $28 \mathrm{~d}$ post-weaning (Quigley and Bernard, 1992). The VFA concentration in low and high feeding level was found similar in $0 \mathrm{~h}$, but tend to different in 3 $\mathrm{h}(\mathrm{P}=0.098)$, and different in $6 \mathrm{~h}(\mathrm{P}=0.035)$. The fact in 3 and $6 \mathrm{~h}$ post feeding which high level feeding give VFA higher than of low feeding level

Table 1. Dry Matter Intake, Feed Digestibilities and Body Weight Gain in Young and Mature Goats with Low and High level of Feeding

\begin{tabular}{|c|c|c|c|c|c|c|}
\hline \multirow{2}{*}{ Parameters } & \multicolumn{2}{|c|}{ Ages } & \multicolumn{2}{|c|}{ Intakes Level } & \multicolumn{2}{|c|}{$P$ value } \\
\hline & Young & Mature & Low & High & Ages & Intakes Level \\
\hline $\mathrm{DMI}(\mathrm{g} / \mathrm{d})$ & 325.29 & 424.88 & 254.50 & 495.67 & 0.011 & $<0.001$ \\
\hline Body weight gain (g/d) & 23.78 & 42.34 & 24.74 & 41.37 & 0.033 & 0.051 \\
\hline Carbohydrate digestible (g/d) & 160.08 & 232.92 & 132.71 & 260.29 & 0.023 & 0.001 \\
\hline Carbohydrate digestibility (\%) & 74.42 & 75.79 & 73.73 & 76.49 & 0.466 & 0.156 \\
\hline Cfi digestible (g/d) & 23.67 & 33.54 & 19.04 & 38.17 & 0.051 & 0.001 \\
\hline Cfi digestibility (\%) & 83.71 & 84.90 & 82.86 & 85.75 & 0.560 & 0.168 \\
\hline OM digestible (g/d) & 221.23 & 320.65 & 184.37 & 357.52 & 0.021 & 0.001 \\
\hline OM digestibility (\%) & 62.64 & 63.03 & 61.09 & 64.58 & 0.896 & 0.252 \\
\hline
\end{tabular}


Table 2. Volatile Fatty Acid (VFA) and Blood Glucose

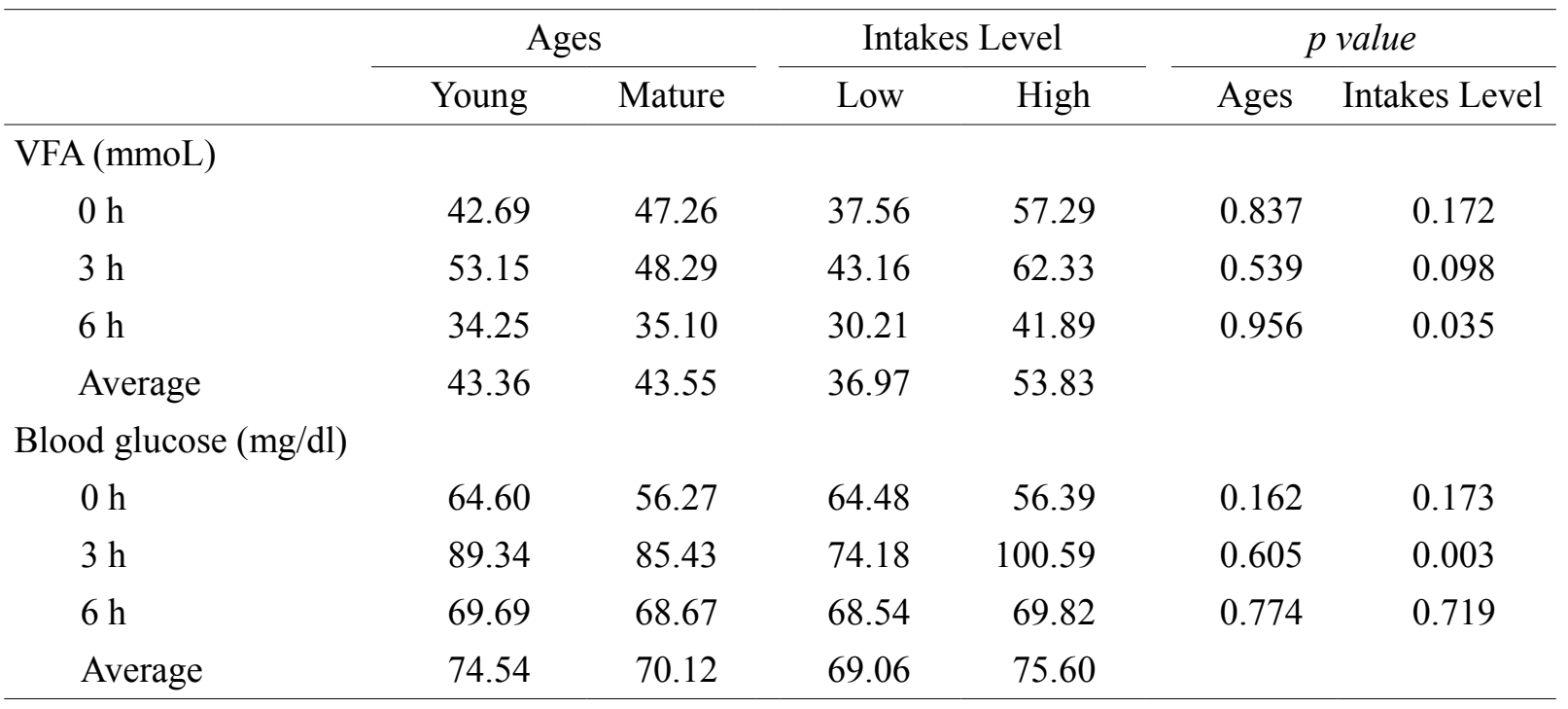

in same feed quality indicated the effect of feeding level on degradation in the rumen. The effect of level feeding in $0 \mathrm{~h}$ was not found, it might be to the very low of feed or degradable feed compounds retained in the rumen. The last feeding time prior to rumen liquid collected was more than $15 \mathrm{~h}$ and may give a lowest degradable fraction in the rumen contents. The difference of VFA concentration in this study was pointed to the carbohydrates contents which was highly fermented by microbes (Sun et al., 2014), the amount of microorganisms in the rumen and the amount of feed intake (Cole et al., 1988; Sano et al., 1999). DMI in this study $(1.83-2.74 \% \mathrm{BW})$ and crude fiber content (ranged at $23.67-38.17$ g) gave VFA concentrations ranged at $30.21-$ $62.33 \mathrm{mmoL}$ ) was relatively lower compared to the study of Ginting et al. (2011) by fed the goat at $3-4 \%$ BW and crude fiber content ranged at 38.7 - $91.9 \mathrm{~g}$ gave VFA concentration ranged at 53-146 mmoL.

Numerically, VFA concentration of young Kacang goats was lower, but the blood glucose were higher than those of mature Kacang goats. The young animals need more of glucose, so the young animals more responsive to increasing blood glucose than mature animals (Bensadoun et al., 1962). This was in agreement with that reported by Kholif et al. (2014) the blood glucose concentrations was increased with increasing VFA.

The increase of VFA concentration and blood glucose is presented in Figure 1. Glucose is the result of absorption of VFA (propionic acid) from rumen in the blood and was used as an energy source.

The VFA increased at $3 \mathrm{~h}$ and then decreased at $6 \mathrm{~h}$. Similar trend was observed in blood glucose. The higher concentration of VFA in $3 \mathrm{~h}$ post feeding was confirmed by Rodriguez et al. (1997) and Lykos et al. (1997). Along with the absorption of VFA, blood glucose was no difference between both ages on 0,3 and $6 \mathrm{~h}$. In 0 $\mathrm{h}$, there was no increase in VFA concentration, so that the blood glucose at $0 \mathrm{~h}$ was not different at the intake level. At $3 \mathrm{~h}$ blood glucose was increased along with increasing VFA concentration on high feeding. However, blood glucose decreased at $6 \mathrm{~h}$, it was suspected that homeostatic mechanism occured in $6 \mathrm{~h}$. If the blood glucose exceed from the range, insulin would be secreted to transport glucose into the cells as glycogen reserves on the liver or muscles. Ginting et al. (2011) reported that Kacang goat fed complete feed showed glucose levels ranged from 27.80 to $61.20 \mathrm{mg} / \mathrm{dl}$. Turner et al. (2005) reported that goats fed alfalfa produced glucose levels at $67.7 \mathrm{mg} / \mathrm{dl}$. Blood glucose was originated from feed source of soluble carbohydrate and rumen fermentation process that could produce propionic acid which was then absorbed through blood circulation and sent to the liver (Tillman et al., 1991). Asmare et al. (2012) showed that the goats given different feeding 


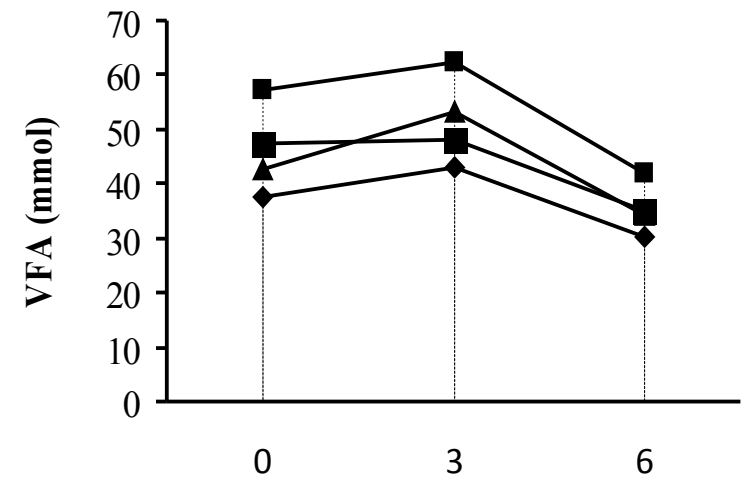

Time (hour)

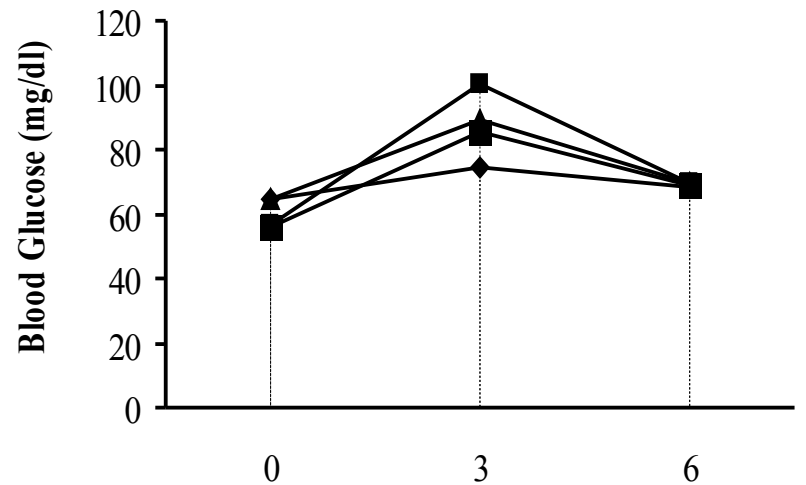

Time (hour)

Figure 1. VFA Concentration and Blood Glucose Over Time for 6 Hours in Kacang Goats. $\bullet$ : low $\rightarrow$ :high $₫$ :young $₫$ :mature 1999).

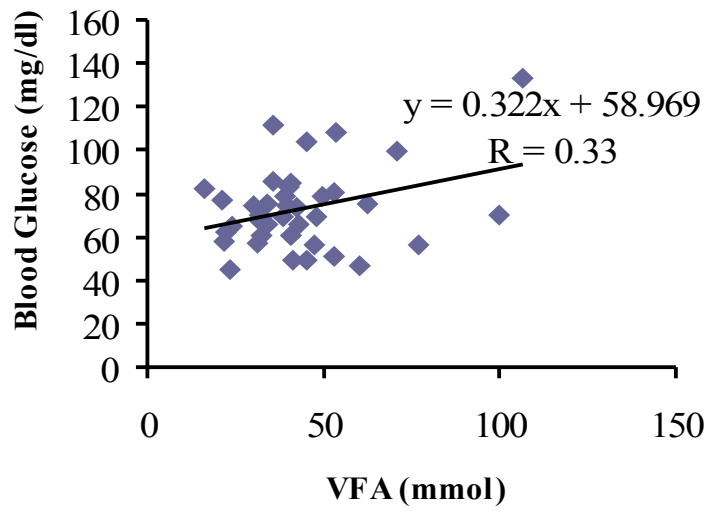

Figure 2. Correlation between Volatile Fatty Acids (VFA) and Blood Glucose

levels (ad libitum and restricted) had similar glucose levels.

Correlation between VFA and blood glucose is presented Figure 2. Blood glucose increased with increasing of VFA. VFA consisted of acetate, butyrate and propionate acid. Propionate was catabolyzed to produce glucose. The correlation of VFA and glucose was found linearly $(\mathrm{r}=0.33)$ which mean that VFA factor only determine $10.91 \%$ of glucose. This suggested that there were other factors affecting the formation of glucose. Glucose is not only produced from the fermentation of carbohydrates in the rumen and or solving the glycogen, but it can be produced from gluconeogenesis (Lykos et al., 1997; Sano et al.,

\section{CONCLUSION}

Based on the results of this study it can be concluded that young and mature Kacang goats fed high level feeding has better feed utilization.

\section{REFFERENCES}

Asmare, A., R. Puchala, K. Tesfai, G.D. Detweiler, L.J. Dawson, A.R. Askar, T. Sahlu and A.L. Goetsch. 2012. Effects of small ruminant type and level of intake on metabolism. Small Ruminant Research 102: 186-190.

Bensadoun, A., O.L. Paladines and J.T. Ried. 1962. Effect of level of intake and physical form of the diet on plasma glucose concentration and vollatile fatty acid absorption in ruminants. J. Dairy Sci. 45:1203-1210.

Bergman, E.N., W.E. Roe and K.Kon. 1966. Quantitative aspects of propionat metabolis and gluconeogenesis in sheep. Am. J. Physiol. 211:793-799.

Cole, N. A., C. W. Purdy and D. M. Hallford. 1988. Influence of fasting and postfast diet energy level on feed intake, feeding pattern and blood variables of lambs. J. Anim. Sci. 66:798-805.

Coomer, J.C., H.E. Amos, C.C. Williams and J.G. Wheeler. 1993. Response of early lactation cows to fat supplementation in diets with 
different non structural carbohydrate concentration. J. Dairy Sci. 76:3747-3754.

Fernandes, M.H.M.R., K. T. Resende, L. O. Tedeschi, J. S. Fernandes, Jr., H. M. Silva, G. E. Carstens, T. T. Berchielli, I. A. M. A. Teixeira and L. Akinaga. 2007. Energy and protein requirements for maintenance and growth of Boer crossbred. J. Anim. Sci. 85:1014-1023.

Ginting, S. P., A. Tarigan and R. Krisnan. 2011. Konsumsi fermentasi rumen dan metabolit darah kambing sedang tumbuh yang diberi silase I.arrecta dalam pakan komplit. Jurnal Ilmu Ternak dan Veteriner. 17(1):49-58.

Gomez K. A. and A.A. Gomez. 1995. Statistical Procedures for Agriculture Research 2nd ed. Indonesia University Press, Jakarta.

Hartadi, H., Reksohadiprodjo, S., and A.D. Tillman. 1997. Tabel Komposisi Pakan untuk Indonesia. Gadjah Mada University Press. Yogyakarta.

Hays, W. G. and J. S. Brinks. 1980. Relationship of Weight and Height to Beef Cow Productivity. J. Anim. Sci. 50:793-799.

Isac, M. D., M. A. Garcia, J. F. Aguilera and E.M. Alcaide. 1994. A comparative study of nutrient digestibility, kinetics of digestion and passage and rumen fermentation pattern in goats and sheep offered medium quality forages at the maintenance level of feeding. Arch. Anim. Nutr. 46:37-50.

Kearl, L. C. 1982. Nutrient Requirements of Ruminants in Developing Countries. International Feedstuffs institute Utah Agricultural Experiment Station. Utah State University, Logan.

Kholif, A.E., H.M. Khattab, A.A. El-Shewy, A.Z.M. Salem, A.M. Kholif, M.M. ElSayed, H.M. Gado, and M.D. Mariezcurrena. 2014. Nutrient digestibility, ruminal fermentation activities, serum parameters and milk production and compotition of lactating goats fed diets containing rice straw treated with pleurotus ostreatus. Asian-Aust. J. Anim. Sci. 27: 357364.

Lewis, R. M. and G. C. Emmans. 2010. Feed intake of sheep as affected by body weight, breed, sex, and feed composition. J. Anim. Sci 88:467-480.

Lykos, T., G. A. Varga, and D. Casper. 1997. Varying degradation rates of total nonstructural carbohydrates : effects on ruminal fermentation, blood metabolites, and milk production and composition in high producing holstein cows. J. Dairy Sci. $80: 3341-3355$.

Petterson, J. A., F. R. Dunshea, R. A. Ehrhardt, and A. W. Bell. 1993. Pregnancy and undernutrition alter glucose metabolic responses to insulin in sheep. J. Nutr. 123: 1286-1295.

Ponto, K.H. and W. G. Bergen. 1974. Developmental aspects of glucose and VFA metabolism in the germfree and conventional ruminant. J. Anim. Sci. 38: 893-899.

Pralomkarn, W., S. Kochapakdee, S. Saithanoo, and B .W. Norton. 1995. Energy and protein utilisation for maintenance and growth of Thai native and Anglo-Nubian X Thai native male weaner goats. Small Rum. Res.16:1320.

Puchala R., A.K. Patra, G. Animut, T. Sahlu and A.L. Goetsch. 2011. Effects of feed restriction and realimentation on mohair fiber growth and tissue gain by growing Angora goats. Livest. Sci.138:180-186.

Rezaei, J., Y. Rouzbehan, H. Fazaeli and M. Zahedifar. 2014. Effects of substituting amaranth silage for corn silage onintake, growth performance, diet digestibility, microbial protein, nitrogen retention and ruminal fermentation in fattening lambs. Anim.Feed Sci. Technol. 192:29-38.

Rodriguez, L.A., C.C. Stallings, J.H. Herbein and M.L. McGilliard. 1997. Diurnal variation in milk and plasma urea nitrogen in holstein and jersey cows in response to degradable dietary protein and added fat. J. Dairy Sci. 80:3368-3376.

Romero-Huelva, M. and E. Molina-Alcaide. 2013. Nutrient utilization, ruminal fermentation, microbial nitrogen flow, microbial abundances, and methane emissions in goats fed diets including tomato and cucumber waste fruits. J. Anim. Sci. 91:914-923.

Sahlu, T., S.P. Hart, and A.L. Goetsch. 1999. Effects of level of feed intake on body weight, body components, and mohair growth in Angora goats during realimentation. Small Rum. Res.32:251-259.

Sano, H., A. Takebayashi, Y. Kodama, K. Nakamura, H. Ito, Y. Arino, T. Fujita, H. Takahashi and K. Ambo. 1999. Effects of feed restriction and cold exposure on glucose metabolism in response to feeding and insulin in sheep. J. Anim. Sci .77:2564- 
2573.

Short R. E. and R. A. Bellows. 1971. Relationships among weight gains, age at puberty and reproductive performance in heifers. J. Anim. Sci 32:127-131.

Sun, H., Y.M. Wu, Y.M. Wang, J.X. Liu and K.H. Myung. 2014. Effects of aspergillus oryzae culture and 2-hydroxy-4-(methylthio)butanoic acid on in vitro rumen fermentation and microbal populations between different roughage sources. Asian-Aust. J. Anim. Sci. 27:1285-1292.

Tillman, A. D., H. Hartadi, S. Reksohadiprodjo, S. Prawirokusumo and S. Labdosoekojo. 1991. Ilmu Makanan Ternak Dasar. Edisi ke-5. Gadjah Mada University Press, Yogyakarta.

Tovar-Luna, I., A.L. Goetsch, R. Puchala, T. Sahlu, G.E. Carstens, H.C. Freetly, and Z.B.
Johnson. 2007. Efficiency of energy use for maintenance and gain by growing crossbred Boer and Spanish Goats consuming diets differing in forage level. Small Rum. Res.67:20-27.

Tovar-Luna, I., R. Puchala, T. Sahlu, H. C. Freetly and A. L. Goetsch. 2011. Effects of level of feeding on energy utilization by Angora goats. J. Anim. Sci. 89:142-149.

Turner K.E, S. Wildeusb, and J.R. Collins. 2005. Intake, performance, and blood parameters in young goats offered high forage diets of lespedeza or alfalfa hay. Small Rum.Res.59:15-23.

Quigley, J. D. and J. K. Bernard. 1992. Effects of nutrient source and time of feeding on changes in blood metabolites in young calves. J. Anim. Sci. 70:1543-1549. 